\title{
Anterolateral Thigh Skin and Fascia in Facial Skin Defects with Trismus: Two Problems, One Solution
}

\author{
Prakash Panagatla ${ }^{1}$ Parvathi Ravula ${ }^{1} \quad$ S. Praveen ${ }^{1} \quad$ Narsimha Rao Varagani ${ }^{2} \quad$ R. Srikanth ${ }^{1}$ \\ Jagadish Kiran Appaka' \\ 1Department of Plastic and Reconstructive Surgery, Nizam's \\ Institute of Medical Sciences, Hyderabad, Telangana, India \\ ${ }^{2}$ Department of Plastic Surgery, KIMS, Narketpalle, Telangana, India

\begin{abstract}
Address for correspondence Parvathi Ravula, MCh,Department of Plastic and Reconstructive Surgery, 4th Floor, Old Building, Nizam's Institute of Medical Sciences, Hyderabad - 500082, Telangana, India (e-mail: paaru_raavula@yahoo.co.in).
\end{abstract}

Indian J Plast Surg 2021;54:192-196.
Abstract
Keywords
- anterolateral thigh flap
- coronoid excision
- condylectomy
- vascularized fascia
- facial skin loss
- necrotizing infection

A case series of five patients with skin loss in the lateral face with trismus that followed delayed presentation following trauma, necrotizing infection, and radiation fibrosis was treated with coronoidectomy and condylar excision to effect adequate mouth opening; the anterolateral thigh flap was used for cover and the fascia was used as an interposition graft to prevent recurrence. Two patients with more than 9 years of follow-up had an average of $40 \mathrm{~mm}$ interincisal opening.

\section{Introduction}

Facial trauma involving the temporo-orbito-zygomatic region may have skin loss precluding primary repair; if the ensuing skin defect is not replaced, healing by secondary intention can lead to trismus. ${ }^{1}$ The trismus that results is usually extra-articular. About $88 \%$ cases of pseudoankylosis are associated with trauma and it complicates up to $0.6 \%$ of undiagnosed zygomatic fractures. ${ }^{2}$

Cervicofacial necrotizing skin and soft tissue infections can be fatal (18-50\%) and can result in extensive skin loss. ${ }^{3}$ Aggressive debridement is often a component of infection control and subsequent wound closure may require free flaps. ${ }^{4}$

Noma can cause extensive soft tissue losses and trismus; excision of fibrosis and flap replacement are combined with a graded approach to maximize mouth opening, setting the basis for rational application of postoperative physiotherapy. ${ }^{5}$

Trismus also may result from soft tissue fibrosis following radiation in head and neck malignancies; the associated chronic radiation dermatitis causes risk of developing skin necrosis, when surgical intervention is needed for restoration of mouth opening.

Any of the conditions described above may present a "double trouble" of facial skin loss, real or apparent (following radiotherapy), and trismus.

We describe the application of free anterolateral thigh (ALT) flap in providing coverage and restitution of adequate mouth opening in patients with facial skin loss and trismus.

\section{Materials and Methods}

A total of five patients (between 2006 and 2017) presented with the common clinical problem of loss of skin or skin atrophy in the lateral part of the face (temporo-orbito-zygomatic region) and trismus, secondary to trauma, infection, and postoperative radiation.

Two patients had defects following delayed presentation of acute traumatic skin loss (with no primary surgical management) and two were following necrotizing facial published online June 22, 2021
DOI https://doi.org/ 10.1055/s-0041-1729504 ISSN 0970-0358
(C) 2021. Association of Plastic Surgeons of India.

This is an open access article published by Thieme under the terms of the Creative Commons Attribution-NonDerivative-NonCommercial-License, permitting copying and reproduction so long as the original work is given appropriate credit. Contents may not be used for commercial purposes, or adapted, remixed, transformed or built upon. (https://creativecommons.org/licenses/by-nc-nd/4.0/).

Thieme Medical and Scientific Publishers Pvt. Ltd. A-12, 2nd Floor, Sector 2, Noida-201301 UP, India 
infection; the fifth patient had surgery for an Ewing sarcoma temporal region and radiotherapy. One of the two patients following acute trauma had fractures of zygoma with loss of the lateral orbital wall.

There were 4 males and 1 female, age group ranging from 23 to 48 years (average, 36.2 years). Time to presentation for treatment was 1 week to 8 years with a mean of 25 months following the primary event. Preoperative interincisal distance was on average $11.4 \mathrm{~mm}$ (range: $10-15 \mathrm{~mm}$; - Table $\mathbf{1}$ ).

\section{Technique}

Nasotracheal intubation was done in four patients, and in one a tracheostomy (Case 5) was done.

Wound debridement and/or scar excision were done to recreate the actual defect. Coronoid excision and excision of the zygomatic arch were done in two patients. In the other three patients, additional excision of the condyle was also done to achieve acceptable mouth opening intraoperatively.

Also, $30 \mathrm{~mm}$ of interincisal opening was taken as the threshold of acceptable mouth opening.

ALT flap was harvested from donor thigh based on the skin defect size; the flap was harvested subfascially. Ipsilateral facial vessels and external jugular vein were dissected and used as recipient vessels. In one patient with postradiation trismus, there was no palpable pulse in the facial and superior thyroid vessels, hence ipsilateral transverse cervical vessels were used.

After the vascular anastomosis, flap vascularity was checked and the fascia was dissected off from the flap at its distal end and interposed between the base of the skull and ramus of the mandible. Retraction of the interposed fascia was prevented by tagging the fascial edge to surrounding tissues using 4-0 absorbable sutures. Skin flap inset was completed as per the defect requirement. All the donor areas, except one, were skin grafted.

Patient were allowed mouth-opening exercises from fifth postoperative day in all but one patient; Heister's mouth screw was used intermittently to give graded mouth-opening therapy. This was advised to be continued for a period of 6 months at the time of discharge.

\section{Results}

Two patients with infection underwent a staged debridement followed by trismus release and flap cover (Cases 2 and 3 ); the gap between the procedures was 23 and 56 days.

Two patients needed excision of the coronoid with or without the zygomatic arch (Cases 1 and 2), and in the other three, further excision of the condyle was done to achieve a minimum of $30 \mathrm{~mm}$ mouth opening at the end of surgery.

All patients were reconstructed using free ALT flap with vascularized fascia; the average flap size was $12 \times 8 \mathrm{~cm}$ and

Table 1 Case-wise details of presentation, defect size, mouth opening, and follow-up result

\begin{tabular}{|c|c|c|c|c|c|}
\hline & Case 1 & Case 2 & Case 3 & Case 4 & Case 5 \\
\hline Cause & RTA & $\begin{array}{l}\text { Necrotizing } \\
\text { Infection }\end{array}$ & Necrotizing infection & RTA & Radiotherapy \\
\hline $\begin{array}{l}\text { Time lag to } \\
\text { presentation }\end{array}$ & 4 months & 1 week & 3 weeks & 2 years & 8 years \\
\hline $\begin{array}{l}\text { Preoperative } \\
\text { mouth opening }\end{array}$ & $10 \mathrm{~mm}$ & $15 \mathrm{~mm}$ & $10 \mathrm{~mm}$ & $12 \mathrm{~mm}$ & $10 \mathrm{~mm}$ \\
\hline $\begin{array}{l}\text { Primary treat- } \\
\text { ment before } \\
\text { referral }\end{array}$ & $\begin{array}{l}\text { Only conservative } \\
\text { treatment for } \\
\text { wounds; } \\
\text { no skeletal } \\
\text { injuries }\end{array}$ & $\begin{array}{l}\text { Diabetic with cuta- } \\
\text { neous zygomycosis; } \\
\text { conservative } \\
\text { treatment for } \\
\text { wounds and antibi- } \\
\text { otic therapy; } \\
\text { no skeletal injuries }\end{array}$ & $\begin{array}{l}\text { Nondiabetic; } \\
\text { nonspecific necrotiz- } \\
\text { ing infection man- } \\
\text { aged with dressings } \\
\text { and antibiotics }\end{array}$ & $\begin{array}{l}\text { Right eye } \\
\text { enucleation; } \\
\text { right below-knee } \\
\text { amputation and } \\
\text { facial wound man- } \\
\text { aged with dressings } \\
\text { only }\end{array}$ & $\begin{array}{l}\text { Left frontotemporal } \\
\text { craniectomy for Ewing } \\
\text { sarcoma followed by } \\
\text { radiotherapy }\end{array}$ \\
\hline $\begin{array}{l}\text { Size and location } \\
\text { of skin loss }(\mathrm{cm})\end{array}$ & $\begin{array}{l}15 \times 10 \text { right tem- } \\
\text { poroparietal area }\end{array}$ & $\begin{array}{l}17 \times 8 \text { right tempo- } \\
\text { ral area and cheek }\end{array}$ & $\begin{array}{l}12 \times 14 \text { right tem- } \\
\text { porofacial area }\end{array}$ & $\begin{array}{l}10 \times 6 \text { infraorbital } \\
\text { and preauricular area }\end{array}$ & $\begin{array}{l}\text { No actual skin loss; } \\
\text { postradiation skin } \\
\text { atrophy needed skin } \\
\text { during closure }\end{array}$ \\
\hline $\begin{array}{l}\text { Ancillaries to } \\
\text { achieve mouth } \\
\text { opening }\end{array}$ & $\begin{array}{l}\text { Right zygomatic } \\
\text { arch excised }\end{array}$ & $\begin{array}{l}\text { Right zygoma arch } \\
\text { and coronoid pro- } \\
\text { cess excision }\end{array}$ & $\begin{array}{l}\text { Right zygoma arch, } \\
\text { coronoid process } \\
\text { excision, } \\
\text { and condylectomy }\end{array}$ & $\begin{array}{l}\text { Right coronoid } \\
\text { excision and } \\
\text { condylectomy }\end{array}$ & $\begin{array}{l}\text { Left } \\
\text { coronoidectomy and } \\
\text { condylectomy }\end{array}$ \\
\hline $\begin{array}{l}\text { Postoperative } \\
\text { mouth opening }\end{array}$ & $30 \mathrm{~mm}$ & $38 \mathrm{~mm}$ & $35 \mathrm{~mm}$ & $37 \mathrm{~mm}$ & $35 \mathrm{~mm}$ \\
\hline $\begin{array}{l}\text { Follow-up } \\
\text { duration }\end{array}$ & $\begin{array}{l}\text { At } 7 \text { months } \\
\text { with no further } \\
\text { follow-up }\end{array}$ & $\begin{array}{l}11 \text { years and on } \\
\text { follow-up }\end{array}$ & $\begin{array}{l}\text { At } 5 \text { months with no } \\
\text { further follow-up }\end{array}$ & $\begin{array}{l}9 \text { years and on } \\
\text { follow-up }\end{array}$ & $\begin{array}{l}34 \text { months and on } \\
\text { follow-up }\end{array}$ \\
\hline $\begin{array}{l}\text { Mouth opening } \\
\text { at follow-up }\end{array}$ & $30 \mathrm{~mm}$ & $44 \mathrm{~mm}$ & $35 \mathrm{~mm}$ & $40 \mathrm{~mm}$ & $27 \mathrm{~mm}$ \\
\hline
\end{tabular}

Abbreviation: RTA, road traffic accident. 
the average size of the vascularized fascia used as interposition graft was $5 \times 3 \mathrm{~cm}$.

One patient (Case 4 ) needed a small segment of the vastus lateralis muscle as filler for the cavitary nature of the wound. Though there was a loss of the lateral wall of the orbit, this was not addressed with skeletal reconstruction. Free ALT flap with fascial extension was harvested along with a part of the vastus lateralis and used as filler for the anterolateral surface of the upper maxilla and the fascia for interposition in the temporomandibular joint area. Only after condylectomy, $37 \mathrm{~mm}$ of mouth opening was achieved intraoperatively (- Figs 1-3).

There were no re-explorations and all the flaps survived; there were two complications.

In one patient (Case 3), two-stage debridement followed by flap was done for sequel of necrotizing infection; facial nerve trunk had also necrosed; a $3 \mathrm{~cm}$ cheek mucosal defect was closed with local hinge flaps; coronoid and condylar excision following wound excision permitted more than $30 \mathrm{~mm}$ mouth opening. The necessity for fascial interposition restricted the skin flap inset in the superior temporal region,
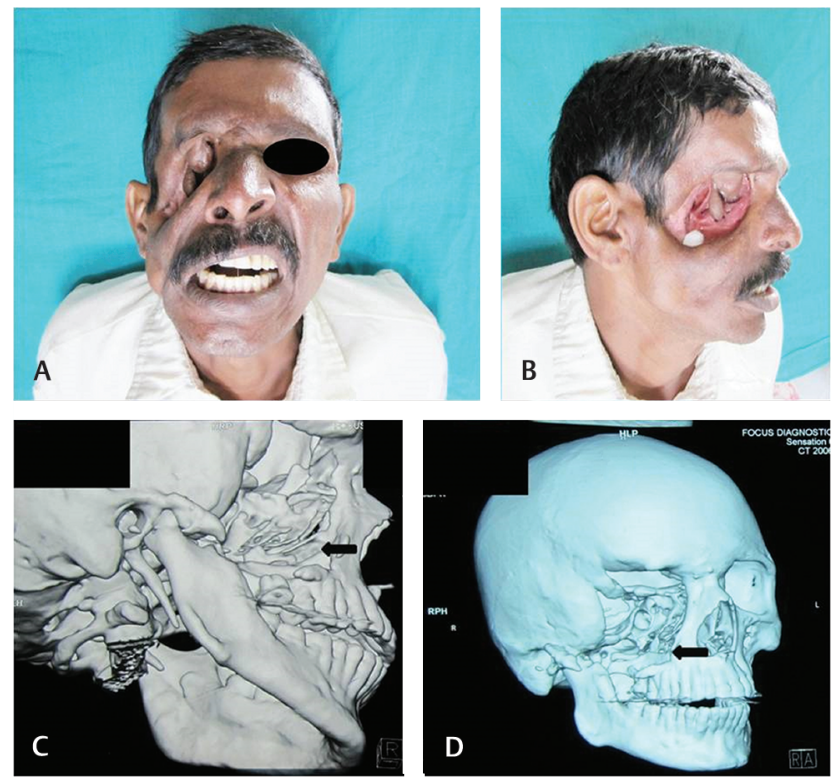

Fig. 1 (A, B) Posttraumatic defect with mouth opening of $12 \mathrm{~mm}$. (C, D) Three-dimensional computed tomography of face showing the extent of the bone defect (bold arrows) and the abnormal condylar head. leading to application of a split skin graft in the superior temporal region (-Figs. 4 and $\mathbf{5}$ ).

Two patients were lost to follow-up after 5 and 7 months; two came for follow-up between 9 and 11 years with mouth opening of 40 to $44 \mathrm{~mm}$. All the patients who needed additional condylar excision had jaw deviation on mouth opening but with normal ability to occlude.

Only two of the five patients (Cases 2 and 5) reported for a second flap-thinning procedure between 4 and 7 months after surgery.

\section{Discussion}

Hill $(1978)^{6}$ described eight cases of cancrum oris with soft tissue loss and mandibular ankylosis. Tube-pedicled flaps from neck and abdomen, with a delay, were used to cover the defects.

Fujioka et $\mathrm{al}^{7}$ reported a case of extra-articular ankylosis of the mandible following radiotherapy for maxillary cancer. Coronoidectomy and a free abdominal flap was used

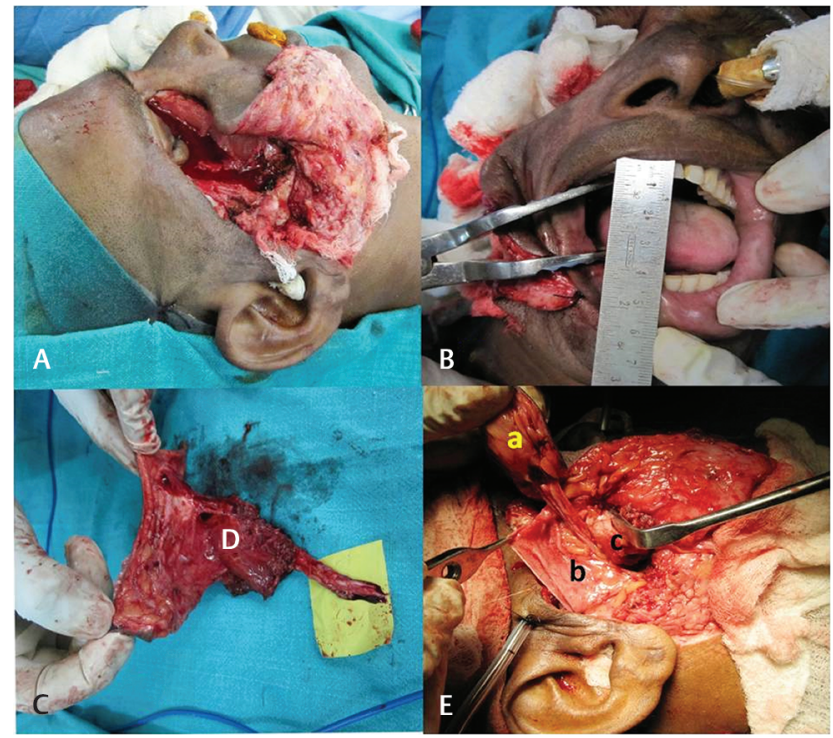

Fig. 2 (A) Postdebridement defect. (B) Intraoperative mouth opening of $37 \mathrm{~mm}$ following release. (C) Anterolateral thigh flap with (D) vastus lateralis muscle. (E) Flap inset using fascia for interpositional arthroplasty (a, flap; b, fascia; c, vastus lateralis).

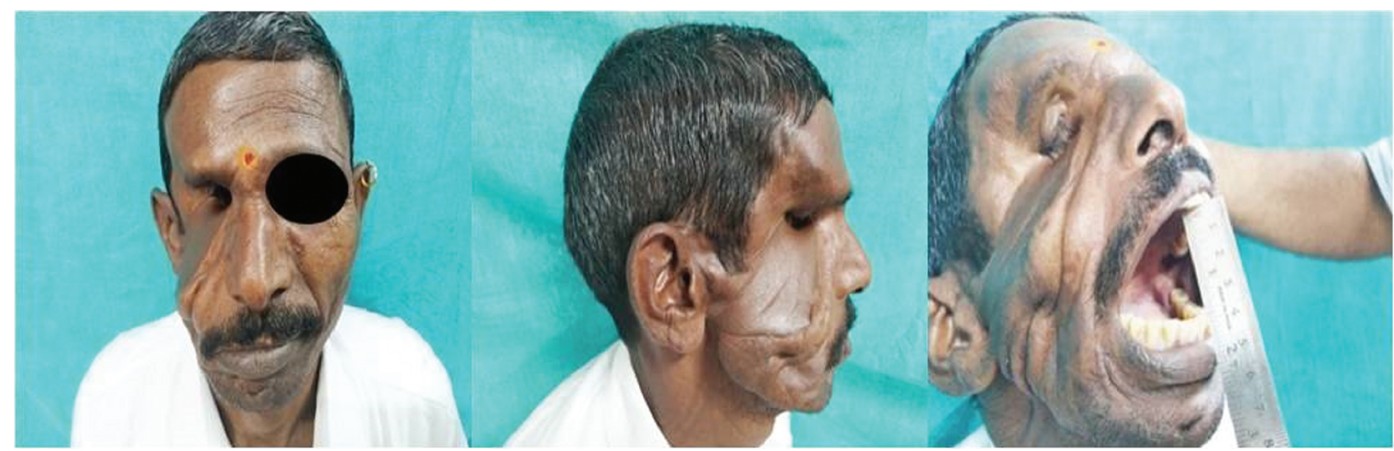

Fig. 3 Follow-up at 9 years with mouth opening of $40 \mathrm{~mm}$. 
to treat ankylosis; the muscle filled the gap following coronoidectomy and the skin replaced the shortage of oral mucosa.

Geissler et $\mathrm{al}^{8}$ described a set of five patients with severe noma-related facial defects and trismus needing free flaps (radial forearm, 2; parascapular flap, 2; latissimus dorsi, 1); the authors used wedge osteotomy to create a large gap, and to prevent reankylosis a dermo-fatty or muscular tail of the
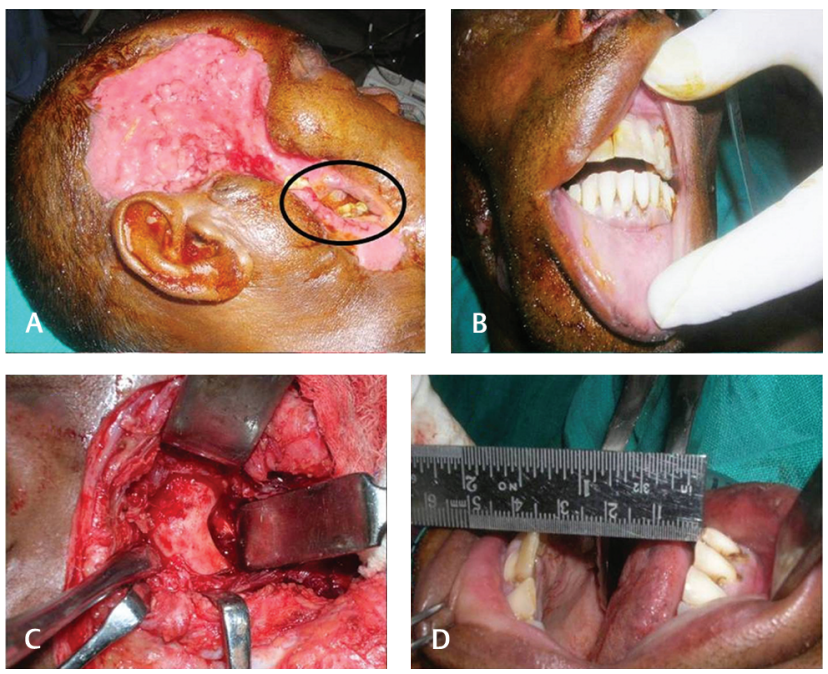

Fig. 4 (A) Postnecrotizing infection and lateral facial defect with fistula (circle). (B) Preoperative mouth opening of $10 \mathrm{~mm}$. (C) Right condyle before removal. (D) Mouth opening of $35 \mathrm{~mm}$ postcondylectomy. free flap was interposed into the gap. The degree of release was dictated by the ability to open the mouth adequately during surgery and not on preoperative imaging.

Though Fechner and Deschler ${ }^{1}$ (2002) in a review article highlight the use of free flaps for coverage and restoration of skeletal continuity, in severe cranio-maxillofacial trauma, the regions of the face covered in this article excludes the lateral facial region. It is this very region where the lack of fascial flaps perfused by the superficial temporal vessels pushes for the use of free flaps.

Dang et $\mathrm{al}^{4}$ demonstrated that in select patients with extensive cervicofacial soft tissue defects after resolution of infection, early free-tissue transfer may be a safe and viable option. In their study, 2 out of 23 necrotizing fasciitis cases needed reconstruction using ALT free flaps.

Fascia lata is strong, pliable, and easily sutured to native tissues. It is homologous tissue with no risk of foreign body reaction. ${ }^{9}$

Seth et $\mathrm{al}^{10}$ demonstrated the use of free-tissue transfer of the ALT fascia lata to recreate the nasal lining. This flap provided a greater source of fascia than the radial forearm free flap.

Functional reconstruction of Achilles tendon injuries with combined soft tissue defects using a free composite ALT flap with vascularized fascia lata has been clinically validated by Houtmeyers et $\mathrm{ll}^{11}$ and Kuo et al. ${ }^{12}$

Our case series had to deal with delayed presentation, poor compliance to postoperative therapy, and the likelihood of default in follow-up.
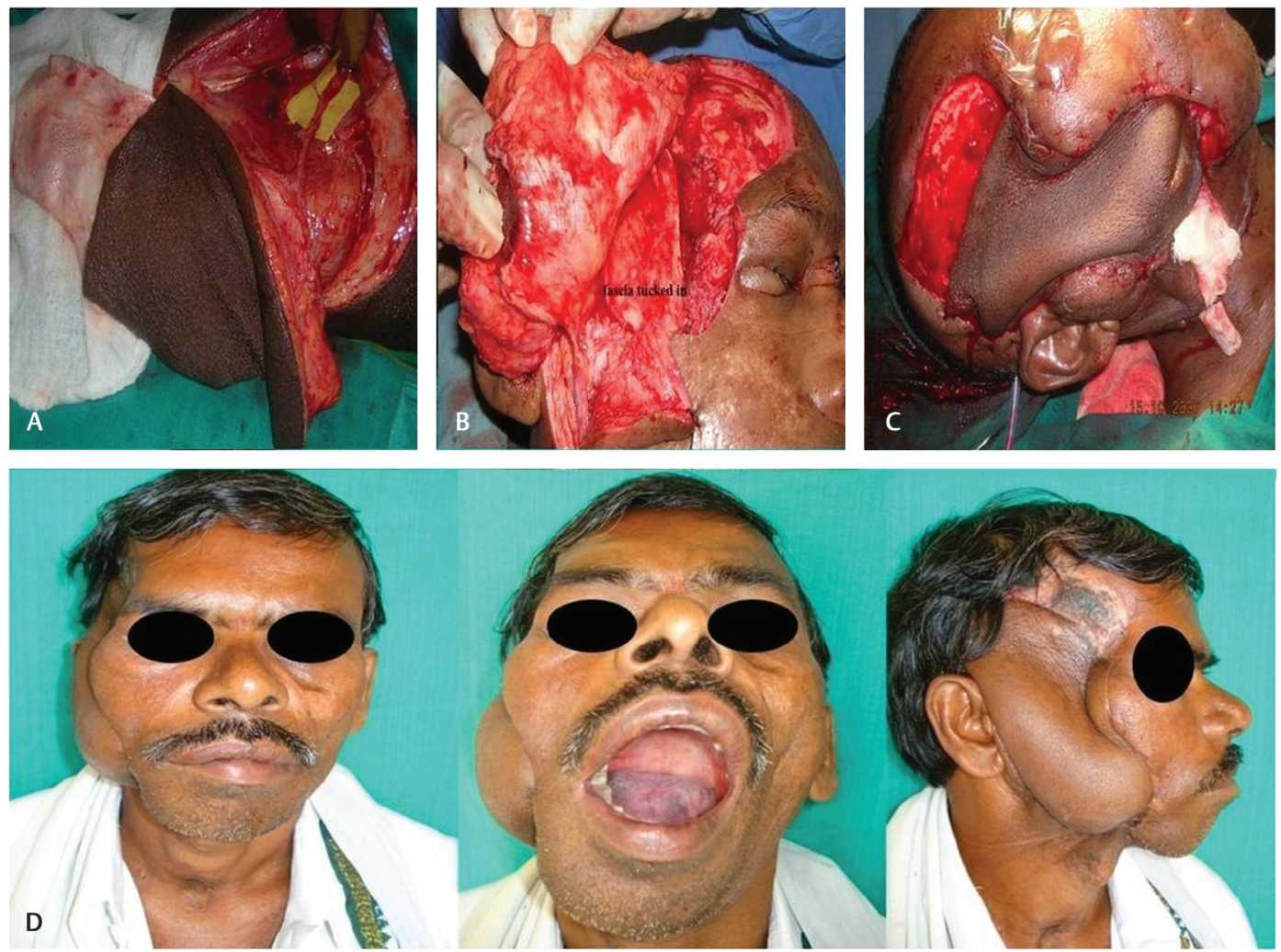

Fig. 5 (A) Anterolateral thigh flap with vascularized fascia as an extension following anastomosis to facial vessels. (B) Fascia tucked in between glenoid and mandible. (C) Flap inset. (D) Adequate mouth opening at 5-month follow-up. 
The condylar resection in three of five cases may appear to be "overkill" for what was largely an extra-articular cause; but in two of five cases following infection, resection of condyle permitted a further increase of 10 to $14 \mathrm{~mm}$ in mouth opening, than with coronoidectomy alone. The threshold of $30 \mathrm{~mm}$ during surgery was imperative to set the stage for postoperative therapy.

Rüegg et al $^{13}$ used an aggressive approach for bilateral coronoid excision and free flap coverage (63 of 121 cases) to get statistically better results in noma-related trismus with facial defects; the mean difference in mouth opening was $8.7 \mathrm{~mm}$ with a $p$-value $\leq 0.0001$.

Twenty-one patients with bilateral coronoidectomy and free flaps (unilateral coronoidectomy with local or free flaps) had better mouth opening than the other groups at all times postoperatively.

\section{Conclusion}

The use of the ALT flap for skin coverage in defects of the temporo-orbito-zygomatic region may be needed for the sequelae of trauma and infection; the availability of vascularized fascia permits its use for interposition following release for the treatment of trismus in extra-articular ankylosis. Excision of the condyle should be considered if the mouth opening achieved by scar and coronoid excision is less than $30 \mathrm{~mm}$. This allows unhindered therapy in the postoperative period and good maintenance of mouth opening in the long term regardless of patient compliance and follow-up. Deviation during attempted mouth opening without malocclusion is a side-effect to be kept in mind.

\section{Conflict of Interest}

None.

\section{References}

1 Fechner FP, Deschler DD. Microvascular free flap reconstruction after craniofacial trauma. Oper Tech Otolaryngol--Head Neck Surg 2002;13(4):309-315
2 Allevi F, Battista V, Moneghini L, Biglioli F. Two typical cases of pseudoankylosis of the jaw: same treatment, different outcome. BMJ Case Rep 2015;2015: bcr201521009910.1136/bcr-2015-210099

3 Bahu SJ, Shibuya TY, Meleca RJ, et al. Craniocervical necrotizing fasciitis: an 11-year experience. Otolaryngol Head Neck Surg 2001;125(3):245-252

4 Dang RP, Bradley JP, Zenga J, Pipkorn P. Microvascular reconstruction after extensive cervical necrotizing fasciitis: a case series. Acta Otolaryngol Case Rep 2019;4(1):21-25

5 Giessler GA, Borsche A, Lim PK, Schmidt AB, Cornelius CP. First experiences with simultaneous skeletal and soft tissue reconstruction of noma-related facial defects. J Reconstr Microsurg 2012;28(2):85-94

6 Hill AJ. Release of mandibular ankylosis due to gross tissue loss in the cheek. Int J Oral Surg 1978;7(4):369-373

7 Fujioka M, Daian T, Murakami R, Makino K. Release of extra-articular ankylosis by coronoidectomy and insertion of a free abdominal flap: case report. J Craniomaxillofac Surg 2000;28(6):369-372

8 Giessler GA, Schmidt AB, Deubel U, Cornelius CP. Free flap transfer for closure and interposition-arthroplasty in noma defects of the lateral face associated with bony ankylosis. J Craniofac Surg 2004;15(5):766-772, discussion 773

9 Alemán RM, Martínez MG. Lateral thigh fascia lata as interpositional graft for temporomandibular joint ankylosis. J Maxillofac Oral Surg 2012;11(3):354-357

10 Seth R, Revenaugh PC, Scharpf J, Shipchandler TZ, Fritz MA. Free anterolateral thigh fascia lata flap for complex nasal lining defects. JAMA Facial Plast Surg 2013;15(1):21-28

11 Houtmeyers P, Opsomer D, Van Landuyt K, Monstrey S. Reconstruction of the Achilles tendon and overlying soft tissue by free composite anterolateral thigh flap with vascularized fascia lata. J Reconstr Microsurg 2012;28(3):205-209

12 Kuo YR, Kuo MH, Chou WC, Liu YT, Lutz BS, Jeng SF. One-stage reconstruction of soft tissue and Achilles tendon defects using a composite free anterolateral thigh flap with vascularized fascia lata: clinical experience and functional assessment. Ann Plast Surg 2003;50(2):149-155

13 Rüegg EM, Baratti-Mayer D, Jaquinet A, Montandon D, Pittet-Cuénod B. The surgical management of extra-articular ankylosis in noma patients. Int $\mathrm{J}$ Oral Maxillofac Surg 2018;47(12):1527-1533 